Quim. Nova, Vol. 35, No. 6, 1118-1122, 2012

\title{
PALLADIUM-SUPPORTED CATALYSTS IN METHANE COMBUSTION. COMPARISON OF ALUMINA AND ZIRCONIA SUPPORTS
}

\author{
Daniela Domingos, Lílian Maria Tosta Simplício Rodrigues*, Soraia Teixeira Brandão, Maria da Graça Carneiro da Rocha \\ e Roger Frety \\ Instituto de Química, Universidade Federal da Bahia, Rua Barão de Geremoabo, s/n, Campus de Ondina, 40170-290 Salvador -
} BA, Brasil

Recebido em 4/8/11; aceito em 6/2/12; publicado na web em 15/5/12

\begin{abstract}
Palladium catalysts supported on alumina and zirconia were prepared by the impregnation method and calcined at 600 and $1000{ }^{\circ} \mathrm{C}$. Catalysts were characterized by BET measurements, XRD, XPS, $\mathrm{O}_{2}$-TPD and tested in methane combustion through temperature programmed surface reaction. Alumina supported catalysts were slightly more active than zirconia supported catalysts, but after initial heat treatment at $1000{ }^{\circ} \mathrm{C}$, zirconia supported palladium catalyst showed better performance above $500{ }^{\circ} \mathrm{C}$ A pattern between temperature interval stability of $\mathrm{PdO}_{\mathrm{x}}$ species and activity was observed, where better $\mathrm{PdO}_{\mathrm{x}}$ stability was associated with more active catalysts.
\end{abstract}

Keywords: palladium; zirconia; methane combustion.

\section{INTRODUCTION}

In the pertinent literature on catalytic combustion of methane, either for low temperature applications such as the removal of traces of methane in the exhaust gases of lean burn natural gas vehicles, or for high temperature applications such as turbine actuation, palladium catalysts have been confirmed as one of the most efficient materials. ${ }^{1-9}$ Some reasons for this include: palladium-based catalysts are extremely active in methane oxidation which guarantees ignition at low temperatures (below $400^{\circ} \mathrm{C}$ ); palladium species formed under reaction conditions (up to $800{ }^{\circ} \mathrm{C}$ ) present low volatility; these systems have the unique capability of temperature self-control associated with the reversible $\mathrm{PdO}$ (active)/Pd (inactive) transformation.

The nature of the support, chemical state, and palladium particle size play an important role in the catalytic behavior of these systems. ${ }^{10,11}$ The role of the support has been widely studied in the literature ${ }^{7,12-17}$ and it has been concluded that the catalytic properties of palladium depend on the nature of the support, which influences palladium-support interaction. Among the various supports used, alumina and zirconia have been the most studied. . $3-5,9,11,13,17-24^{-1}$

The support most commonly used for Pd catalysts is alumina and many studies focusing on $\mathrm{Pd} /$ alumina catalysts are available..$^{10,11,18}$ However, alumina is not fully stable at the high temperatures reached in methane combustion as it undergoes a phase change at $800{ }^{\circ} \mathrm{C}$ from $\gamma$-alumina to $\delta$-alumina, resulting in a loss of surface area. ${ }^{23}$ Hoflund et al. ${ }^{24}$ studied $\mathrm{CeO}_{2}, \mathrm{ZrO}_{2}$ and $\mathrm{MnO}_{2}$ as supports in nanocrystalline and polycrystalline form. These authors found that nanocrystalline $\mathrm{ZrO}_{2}$ and $\mathrm{CeO}_{2}$ supports showed appreciable activities below $300{ }^{\circ} \mathrm{C}$. $\mathrm{ZrO}_{2}$ has also been used as a support by other researchers. ${ }^{20-22}$

With respect to the active phase, a number of studies ${ }^{20,25-30}$ have attempted to define the chemical state of the active phase of the palladium species during catalytic combustion, and it is generally agreed that $\mathrm{PdO}_{\mathrm{x}}$ species are essential, at least below $700-800{ }^{\circ} \mathrm{C}$, where $\mathrm{PdO}_{\mathrm{x}}$ species should be thermodynamically stable. Whether metallic palladium is also permanently present for the dissociative adsorption of methane or participates in the catalytic cycle, formed

*e-mail: mlilian@ufba.br by the reduction of $\mathrm{PdO}_{\mathrm{x}}$ by methane and destroyed by reoxidation with oxygen, remains a matter of debate.

More recently, studies using in situ observation techniques such as XANES, high temperature XRD and Raman spectroscopy under catalytic conditions, have clearly shown that palladium activity increases when $\mathrm{PdO}_{\mathrm{x}}$ species are formed and decreases when metallic palladium appears. ${ }^{31,32}$ However, these techniques are unable to detect traces of either chemical states of palladium. Due to the fact that $\mathrm{PdO}_{x}$ is necessary for good catalytic activity, various studies have examined the possibility of controlling and changing $\mathrm{PdO}_{x}$ stability, firstly by altering the support material and mean particle diameter of the palladium species, secondly by introducing promoters either on the metal or in the support, and lastly by using a large number of preparation techniques. No clear conclusions have yet been drawn from these studies: quantitative amounts of oxidized palladium cannot be linked directly to catalytic activity.

The aim of the present study was to perform new experimental work on this issue by comparing palladium supported on both alumina and zirconia, submitted to either moderate $\left(600^{\circ} \mathrm{C}\right)$ or high $\left(1000^{\circ} \mathrm{C}\right)$ temperature treatments after preparation.

\section{EXPERIMENTAL}

\section{Catalyst preparation}

Alumina Pural SB from Condea and a zirconia sample supplied by the Politecnico di Milano were used as supports and calcined at $600{ }^{\circ} \mathrm{C}$ before use. The impregnation of the supports was performed with a solution of palladium acetylacetonate (supplied by Merck) in toluene (Baker). The supports in powder form were suspended in a toluene solution and submitted to $24 \mathrm{~h}$ agitation in a rotating evaporator at room temperature. The solvent was then evacuated at $100^{\circ} \mathrm{C}$ and final drying at $110^{\circ} \mathrm{C}$ was performed under constant agitation. The dried material was then heat treated either at 600 or at $1000{ }^{\circ} \mathrm{C}$ under flowing air for $10 \mathrm{~h}$. The samples were labelled $\mathrm{P}$ for palladium, and $\mathrm{A}$ and $\mathrm{Z}$ for alumina and zirconia carriers, respectively, and with a 6 or 10 when the final temperature of the heat treatment was 600 or $1000{ }^{\circ} \mathrm{C}$, respectively. AP6 therefore denotes $\mathrm{Pd} / \mathrm{Al}_{2} \mathrm{O}_{3}$ heat treated at $600{ }^{\circ} \mathrm{C}$ at the end of the preparation. 


\section{Characterization of catalysts}

The surface area of the supports was measured using the BET method and adsorption equipment (ASAP 2000). Before analysis, the samples were out-gassed under a vacuum at $350{ }^{\circ} \mathrm{C}$ for $3 \mathrm{~h}$.

XRD measurements were performed with a Shimadzu XRD-6000 apparatus. The following experimental conditions were used: $2 \theta$ range $=10-80^{\circ}$, step size $=0.02^{\circ}$, time per step $=4.80 \mathrm{~s}$ and CuK $\alpha$ radiation $(\lambda=1.5418 \AA$ ). The powder samples were analyzed without previous treatment. Palladium oxide crystallite sizes were estimated from the Debye Scherrer Equation using the measured width at half peak height of the $\mathrm{PdO}$ main diffraction peak $(2 \theta=$ 33.88) for the 101 plan.

$$
\tau_{P d O}=\frac{K \cdot \lambda}{b \cdot \cos \theta}
$$

$\tau_{\mathrm{PdO}}=\mathrm{PdO}$ crystallite size $; \lambda=\mathrm{X}$-ray wavelength, $1.5418 \AA$ for $\mathrm{CuK} \alpha ; \theta=$ observed peak angle in degrees ; $\mathrm{K}=$ crystallite-shape factor $\approx 1 ; \mathrm{b}=$ measured peak width in radians at half peak height.

XPS spectra were recorded with an Escalab VG MK1 spectrometer (Vacuum Generator) operating at a constant pass energy $(50 \mathrm{eV})$, with an unmonochromated $\mathrm{Mg} \mathrm{K} \alpha$ source $(200 \mathrm{~W})$ at a pressure of $10^{-8}$ mbar. The binding energies of palladium species (BE) were referenced to that of the $\mathrm{C} 1 \mathrm{~s}(285.0 \mathrm{eV})$.

The palladium content in the samples was measured by X-ray Fluorescence using a Shimadzu XRF 1800 apparatus.

The stability of the $\mathrm{PdO}_{x}$ species was studied using the TPD technique. A total of $0.1 \mathrm{~g}$ catalyst diluted with $0.1 \mathrm{~g}$ of quartz powder was loaded in a quartz micro-reactor and heated in a He flow $\left(30 \mathrm{~mL} / \mathrm{min}\right.$ ) at a rate of $10^{\circ} \mathrm{C} / \mathrm{min}$. Before TPD, the samples were heat treated under a flow of $5 \% \mathrm{O}_{2}$ in $\mathrm{He}$, up to the initial calcining temperature and cooled down to room temperature under the same mixture. The $\mathrm{O}_{2}$ Helium mixture was then changed to pure $\mathrm{He}$ and TDP initiated. $\mathrm{O}_{2}$ release was monitored using a quadrupole mass spectrometer (Balzers QMS 200, m/e = 32).

The temperature-programmed catalytic tests (TPSR) were performed on a quartz micro-reactor loaded with $0.1 \mathrm{~g}$ catalyst diluted in $0.1 \mathrm{~g}$ quartz powder. The temperature of the reaction was measured by a K-type thermocouple located in a quartz compartment beside the catalyst bed. The samples were heated to either 600 or $1000{ }^{\circ} \mathrm{C}$, under a flowing mixture of $0.5 \% \mathrm{CH}_{4}, 2 \% \mathrm{O}_{2}$ and $97.5 \% \mathrm{~N}_{2}(100 \mathrm{~mL} /$ $\min$ ) at a heating rate of $10{ }^{\circ} \mathrm{C} / \mathrm{min}$. Under the conditions applied, GHSV was close to $60000 \mathrm{~h}^{-1}$. Effluent gases were analyzed by mass spectrometry (Balzers QMS 200) and the following mass-to-charge ratios $(\mathrm{m} / \mathrm{e})$ were used to monitor the concentrations of products and reactants: $\mathrm{CH}_{4}\left(\mathrm{~m} / \mathrm{e}=15\right.$ and 16), $\mathrm{H}_{2} \mathrm{O}(\mathrm{m} / \mathrm{e}=18), \mathrm{CO}(\mathrm{m} / \mathrm{e}=28)$, $\mathrm{O}_{2}(\mathrm{~m} / \mathrm{e}=32)$ and $\mathrm{CO}_{2}(\mathrm{~m} / \mathrm{e}=44)$.

The conversion of methane was calculated using Equation 2, where $C_{A}$ represents the $m / e=15$ signal recorded in the mass spectrometer (proportional to the methane concentration), $\mathrm{C}_{\mathrm{AO}}$ represents the $\mathrm{m} / \mathrm{e}=15$ initial signal and $\mathrm{X}$ the methane conversion.

$$
X=\frac{C_{A o}-C_{A}}{C_{A o}}=1-\frac{C_{A}}{C_{A o}}
$$

\section{RESULTS AND DISCUSSION}

Table 1 shows the results for surface area, porosity and crystallinity of the supports.

From the data given in Table 1, the supports appeared to undergo significant transformation during the heat treatment between 600 and $1000{ }^{\circ} \mathrm{C}$, as the surface area of both carriers shows a decrease by a factor of 3 . Whereas the monoclinic structure of zirconia is maintained following the increase in temperature from 600 to $1000{ }^{\circ} \mathrm{C}$, alumina exhibits structural transformation from $\gamma$ phase to a mixture of $\theta, \gamma$ and $\delta$ phases. These results are in agreement with data from the literature. ${ }^{33,34}$ In parallel, porous volume is reduced after calcining at $1000{ }^{\circ} \mathrm{C}$, an observation also fully coherent with the reduction in surface area.

Table 1. Textural and crystallographic data for the alumina and zirconia supports, after heat treatment at 600 and $1000{ }^{\circ} \mathrm{C}$

\begin{tabular}{cccc}
\hline Sample & $\begin{array}{c}\text { Surface area } \\
\mathrm{m}^{2} / \mathrm{g}\end{array}$ & $\begin{array}{c}\text { Porous volume } \\
\mathrm{cm}^{3} / \mathrm{g}\end{array}$ & Crystalline phases \\
\hline $\mathrm{A} 6$ & 179 & 0.5 & $\gamma-\mathrm{Al}_{2} \mathrm{O}_{3}$ \\
$\mathrm{~A} 10$ & 63.2 & 0.31 & $\gamma-\mathrm{Al}_{2} \mathrm{O}_{3}, \delta-\mathrm{Al}_{2} \mathrm{O}_{3}, \theta-\mathrm{Al}_{2} \mathrm{O}_{3}$ \\
$\mathrm{Z} 6$ & 28.9 & 0.15 & monoclinic \\
$\mathrm{Z} 10$ & 9.6 & 0.06 & monoclinic* \\
\hline
\end{tabular}

* Better crystallization

Table 2 shows the surface area of the catalysts, together with their porosity, and $\mathrm{Pd}$ content. Table 2 also shows $\mathrm{Pd} 3 \mathrm{~d}_{5 / 2}$ binding energy and values of $\mathrm{Pd} / \mathrm{Al}$ and $\mathrm{Pd} / \mathrm{Zr}$, i.e. an estimation of the surface coverage of palladium for the different catalysts, as measured by XPS.

The data in Table 2 indicates that the surface area of the supported catalysts is close to that of the pure supports. This is un surprising since the impregnation method using an acetylacetonate precursor, in organic medium, cannot substantially alter the surface structure of the support as sometimes occurs when impregnation is performed under basic or acidic medium. Under such conditions, the support material can be partially leached thus, inducing a deposition on the carrier not only of the active phase, but also of the dissolved carrier species during the drying process. Further, the amount of palladium used, close to $1 \mathrm{wt} \%$, is relatively small and similar for all four catalysts. Therefore, the present impregnation method cannot produce significant changes in the textural properties of the supports.

The $P d 3 d_{5 / 2}$ binding energy values obtained by XPS are also shown in Table 2, indicating that Pd is predominantly in an oxidized form for all samples, corroborating previous reports. ${ }^{35-39}$ Whether the $\mathrm{PdO}_{\mathrm{x}}$ are similar or differ among the present samples is hard to ascertain as the sensitivity of the equipment was limited. However, it is clear that the decrease in the surface palladium species disclosed by XPS

Table 2. Textural, chemical and XPS properties of supported Pd catalysts, heat treated at 600 and $1000{ }^{\circ} \mathrm{C}$

\begin{tabular}{cccccc}
\hline Sample & Surface area $\left(\mathrm{m}^{2} / \mathrm{g}\right)$ & Porous volume $\left(\mathrm{cm}^{3} / \mathrm{g}\right)$ & $\mathrm{Pd}$ content $(\mathrm{wt} \%)$ & ${\mathrm{BE} \mathrm{Pd} 3 \mathrm{~d}_{5 / 2}(\mathrm{eV})}^{\mathrm{Pd} / \mathrm{Al} \text { or Pd} / \mathrm{Zr}}$ \\
\hline AP6 & 178 & 0.44 & 0.94 & 336.7 & 337.4 \\
AP10 & 58 & 0.23 & 0.98 & 336.6 & 0.006 \\
ZP6 & 33.2 & 0.14 & 0.95 & 336.0 & 0.004 \\
ZP10 & 6 & 0.03 & 0.96 & 064 & 0.024 \\
\hline
\end{tabular}

Pd content was measured by X-Ray Fluorescence, $\mathrm{Pd} 3 \mathrm{~d}_{5 / 2}$ binding energy (BE) and $\mathrm{Pd} / \mathrm{Al}$ (Pd/Zr) were calculated from XPS data. 
is much more pronounced than the decrease of the supports surface areas, as the values of the ratios $\mathrm{Pd} / \mathrm{Al}$ or $\mathrm{Pd} / \mathrm{Zr}$ decreased more than the surface area of the supports after the heat treatment at $1000{ }^{\circ} \mathrm{C}$.

However, it is not known at this stage whether the decrease in $\mathrm{Pd} /$ $\mathrm{Al}(\mathrm{Pd} / \mathrm{Zr})$ is simply due to the sintering of the palladium species, to a kind of SMSI ${ }^{40}$ implying a migration of some support moieties on top of the palladium particles, or both these effects. Although generally crystallite sizes and particle sizes are not simply correlated, the crystallite sizes of $\mathrm{PdO}_{x}$ were calculated using the Debye-Scherrer equation applied to the $\mathrm{PdO}$ main diffraction peak $\left(2 \theta=34^{\circ}\right)$ in all catalysts.

Figure 1 shows the deconvolution of the XRD profile close to the [101] line of $\mathrm{PdO}$ at $2 \theta=34^{\circ}$. In this case, the mean crystallite size for $\mathrm{PdO}_{x}$ was estimated to be 28 and $36 \mathrm{~nm}$ for ZP6 and ZP10, respectively, a less pronounced variation than that estimated through the variations of $\mathrm{Pd} / \mathrm{Zr}$. In other words, the thermal treatment at $1000{ }^{\circ} \mathrm{C}$ seems to induce both a sintering of $\mathrm{PdO}_{\mathrm{x}}$ and partial covering of the $\mathrm{PdO}_{\mathrm{x}}$ by zirconia moieties. Similar patterns were also observed in alumina samples, although in this case the deconvolution was of limited quality, due to interferences between alumina and $\mathrm{PdO}_{\mathrm{x}}$ lines.
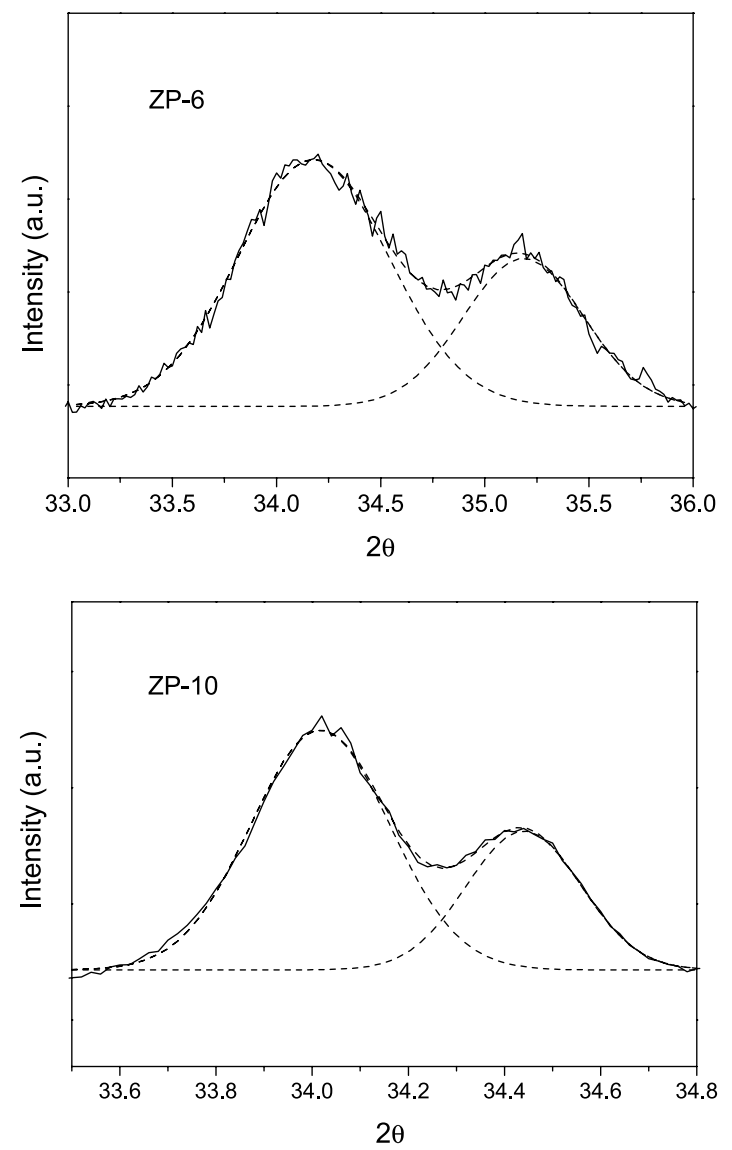

Figure 1. Window of XRD spectrum where the [101] line of PdO appears for ZP-6 ad ZP-10 catalysts. Deconvolution of the experimental spectrum (dash lines); experimental spectrum (solid lines)

Figure 2 shows the TPD spectra of AP6, AP10, ZP6 and ZP10. In all cases, $\mathrm{PdO}_{\mathrm{x}}$ species appear stable up to $570-580{ }^{\circ} \mathrm{C}$, and fully decomposed above $900-950{ }^{\circ} \mathrm{C}$, values in strong agreement with literature data. ${ }^{31,32}$ The maximum decomposition temperature was $791,733,847$ and $722{ }^{\circ} \mathrm{C}$, for AP6, AP10, ZP6 and ZP10 respectively. Two main points warrant closer analysis. The first is the fact that $\mathrm{PdO}_{\mathrm{x}}$ is less stable after heat treatment of the catalysts at $1000^{\circ} \mathrm{C}$ than after a calcining temperature of $600^{\circ} \mathrm{C}$. After calcining at $1000{ }^{\circ} \mathrm{C}$, the temperature at the beginning of $\mathrm{PdO}_{\mathrm{x}}$ decomposition is lower or similar to the value after heat treatment at $600{ }^{\circ} \mathrm{C}$, while the temperature at the end of the decomposition is also significantly decreased. This implies that the particles of $\mathrm{PdO}_{\mathrm{x}}$ are less stable when their size increases, or that their interaction with the support is more limited. Regardless of the exact reason, the instability domain for the $\mathrm{PdO}_{\mathrm{x}}$ species must influence the results of the catalytic methane combustion.

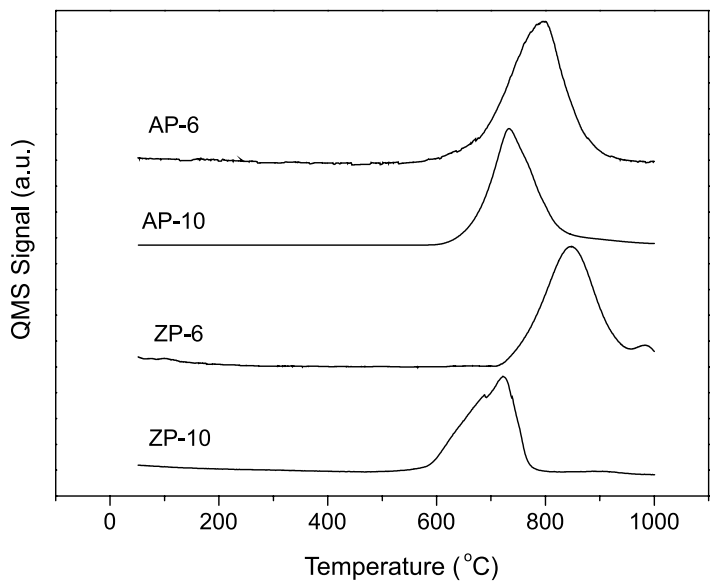

Figure 2. Oxygen TPD profile, under He flow, for the catalysts AP-6, AP-10, $\mathrm{ZP}-6$ and $\mathrm{ZP}-10$

The second point relates to the comparison between alumina- and zirconia-supported palladium. $\mathrm{PdO}_{\mathrm{x}}$ species supported on zirconia have been observed to be much less stable than on alumina by Farrauto et al..$^{41}$ The present results showed that this is not always the case and that the history of the catalysts, nature of the support, as well as the preparation method, all influence the behavior of $\mathrm{PdO}_{\mathrm{x}}$ entities, implying that the definition of an optimized catalyst for methane combustion is rather more complex.

Figures 3 and 4 depict the TPSR curves for the 4 catalysts. For experimental reasons, the TPSR was stopped at $600{ }^{\circ} \mathrm{C}$ for the AP6 and ZP6 catalysts, but was continued up to $1000{ }^{\circ} \mathrm{C}$ for the samples $\mathrm{AP} 10$ and ZP10.

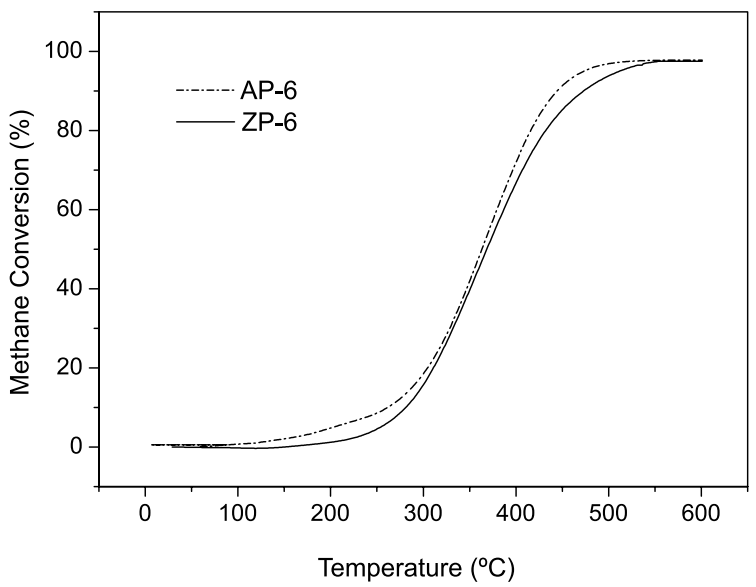

Figure 3. TPSR curves of the catalysts ZP-6 and ZP-10 during methane combustion

The relation between conversion of methane and temperature increase is very different in both cases. Reiterating, the lower the temperature required to reach a given conversion, the more active 


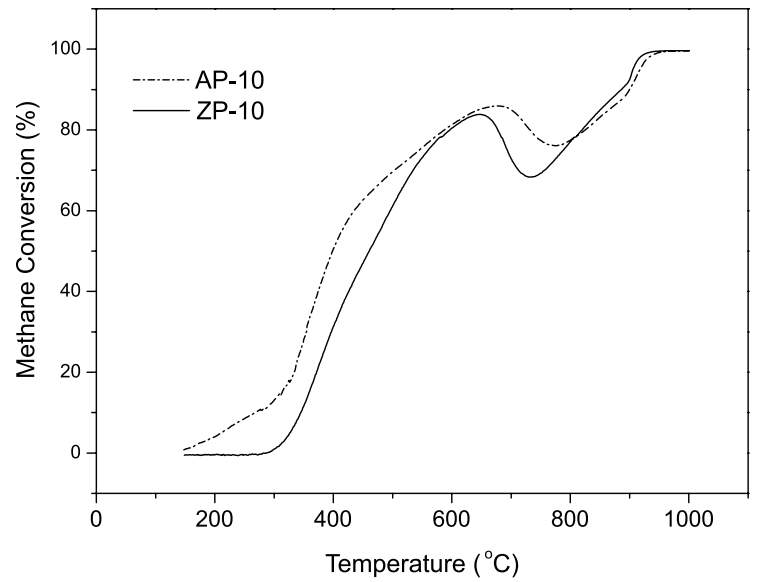

Figure 4. TPSR curves of the catalysts AP-6 and AP-10 during methane combustion

the catalyst. For AP6 and ZP6, the two curves are fairly similar a though the AP6 sample is more active than the ZP6 over the whole temperature range. This is evidenced by the values given in Table 3, showing the temperatures at which conversions are 10, 50 and $80 \%$ respectively.

Table 3. Temperatures observed at $\mathrm{CH}_{4}$ iso-conversion (10,50 and $80 \%$ respectively) obtained by TPSR technique in Figures 3 and 4, for the AP6, ZP6, AP10 and ZP10 catalysts

\begin{tabular}{cccc}
\hline Catalyst & $\mathrm{T}_{10 \%}\left({ }^{\circ} \mathrm{C}\right)$ & $\mathrm{T}_{50 \%}\left({ }^{\circ} \mathrm{C}\right)$ & $\mathrm{T}_{80 \%}\left({ }^{\circ} \mathrm{C}\right)$ \\
\hline AP6 & 248 & 340 & 412 \\
ZP6 & 270 & 350 & 420 \\
AP10 & 250 & 395 & $600 ; 720 ; 830^{*}$ \\
ZP10 & 300 & 405 & $585 ; 670 ; 800^{*}$ \\
\hline
\end{tabular}

$\mathrm{T}_{\mathrm{x} \%}=$ Temperature observed for $\mathrm{x} \%$ methane conversion. $*$ The three different temperatures noted at $80 \%$ conversion for AP-10 and ZP-10 are due to the decrease followed by an increase of conversion in the high temperature range.

Comparing the conversion to the stability of $\mathrm{PdO}_{x}$ as measured by oxygen TPD revealed that the whole conversion occurs over a temperature range in which $\mathrm{PdO}_{\mathrm{x}}$ is completely stable for both AP6 and ZP6. Due to the high activity observed, no clear difference can be seen between the two catalysts under the experimental conditions applied.

The situation is more complex concerning the catalysts heat treated at $1000{ }^{\circ} \mathrm{C}$ before catalytic measurements. The first point worthy of comment is the fact that both catalysts were less active than preceding ones, as an increase of at least 30 to $40{ }^{\circ} \mathrm{C}$ is required to achieve $50 \%$ conversion. Furthermore, above around $400{ }^{\circ} \mathrm{C}$, the increase in conversion when increasing temperature is slowed down, and above approximately $650{ }^{\circ} \mathrm{C}$, as seen in the literature,,$^{31,32}$ causes a drop in activity. Between 630 and around $830^{\circ} \mathrm{C}$, activity is lower than that obtained at $625^{\circ} \mathrm{C}$. Whereas AP10 is more active than ZP10 up to $500{ }^{\circ} \mathrm{C}$, the opposite is true at temperatures between 625 and $900{ }^{\circ} \mathrm{C}$ ( see $\mathrm{T}=80 \%$ conversion in Table 3 ).

The decrease in conversion at increasing temperatures has been observed in numerous studies and was attributed to the decomposition of $\mathrm{PdO}_{x}$ species to metallic palladium, a much less active substance than $\mathrm{PdO}_{\mathrm{x}}$ over this temperature range. The same interpretation holds for the present results. However, it is notable here that despite slightly better activity of ZP10 in comparison with AP10 between 500 and $625^{\circ} \mathrm{C}$, the drop in activity is more rapid with this catalyst than with AP10, between 625 and $700{ }^{\circ} \mathrm{C}$. Examining the oxygen TPD curves of Figure 2 reveals that $\mathrm{PdO}_{\mathrm{x}} / \mathrm{ZP} 10$ decomposes more easily than $\mathrm{PdO}_{\mathrm{x}} / \mathrm{AP} 10$, an observation in complete agreement with catalytic behavior. Although much less sophisticated that the in situ experiments of Grunwaldt et al. ${ }^{31}$ the findings of the present experiments using simple oxygen TPD are in complete agreement with the observations of these authors.

A further point for analysis upon observing the conversion curves versus temperature for catalysts $\mathrm{AP} 10$ and ZP10 is that at temperatures above about $400{ }^{\circ} \mathrm{C}$, the increase in conversion with temperature increase is less efficient than expected from an exponential conversion increase versus temperature. This suggests that above $400{ }^{\circ} \mathrm{C}$ physical transformations of the catalysts tested occur. We may speculate that over this temperature range $\mathrm{PdO}_{\mathrm{x}}$ particles begin to transform into metallic $\mathrm{Pd}$, leading to a decrease in the active area of $\mathrm{PdO}_{\mathrm{x}} \cdot{ }^{1,3,10,18}$ The whole transformation is accomplished when the TPSR curves were at their minimum above temperatures of $700{ }^{\circ} \mathrm{C}$. The further activity increase above this temperature is due to the fact that metallic $\mathrm{Pd}$ particles are now the main active species, whose activity increases with temperature as expected. The differences in the $\mathrm{PdO}_{\mathrm{x}}$ stability temperature range when comparing the oxygen TPD curves and the anomalous behavior of the catalysts on TPSR curves is probably due to differences in oxidizing potential of the atmosphere surrounding the $\mathrm{Pd} / \mathrm{PdO}_{\mathrm{x}}$ species in both experiments.

Finally, it was observed that at temperatures higher than $500{ }^{\circ} \mathrm{C}$, the ZP10 catalyst is more active than the AP10 sample. Taken together with the difference in $\mathrm{PdO}_{\mathrm{x}}$ stability discussed previously, it is possible to deduce that some oxygen species of the zirconia support is involved in the catalytic process, through a kind of bulk oxygen migration ${ }^{28}$ mediated by the palladium species. Such a phenomenon cannot exist with the alumina support because oxygen is very strongly bound to aluminum.

\section{CONCLUSIONS}

The present study has shown that the palladium catalysts prepared through impregnation with palladium acetylacetonate are quite active in the conversion of methane, especially at low temperatures, and particularly when the catalysts have been heat treated before use at a temperature of around $600{ }^{\circ} \mathrm{C}$. An increase in the preparation temperature to $1000{ }^{\circ} \mathrm{C}$ generates catalysts with a lower $\mathrm{PdO}_{\mathrm{x}}$ active area that are less active than the catalysts prepared at $600{ }^{\circ} \mathrm{C}$ under the reaction conditions applied in this work. A clear pattern appears between $\mathrm{PdO}_{x}$ stability and activity, mainly over the temperature range in which $\mathrm{PdO}_{x}$ showed instability. The present results suggest that it is possible to modify $\mathrm{PdO}_{\mathrm{x}}$ stability by for example, changing the size of $\mathrm{PdO}_{x}$ particles and their support, at least at temperatures lower than $600{ }^{\circ} \mathrm{C}$, and also that TPD of oxygen during the decomposition of $\mathrm{PdO}_{\mathrm{x}}$ is a powerful tool for optimizing this family of combustion catalysts.

\section{ACKNOWLEDGMENTS}

R. Frety thanks FAPESB (Fundação de Apoio à Pesquisa do Estado da Bahia) for a grant during the period 2009-2010 and CNPq for a grant during a 6 months period in 2011 .

\section{REFERENCES}

1. Groppi, G.; Cristiani C.; Lietti, L.; Ramella, C.; Valentini, M.; Forzatti, P.; Catal. Today 1999, 50, 399.

2. Geus, J. W.; Van Giezen, J. C.; Catal. Today 1999, 47, 169.

3. Centi, G.; J. Mol. Catal. A: Chem. 2001, 173, 287. 
4. Choudhary, T. V.; Banerjee, S.; Choudhary, V. R.; Appl. Catal., A 2002, $234,1$.

5. Forzatti, P.; Catal. Today 2003, 83, 3.

6. Gélin, P.; Urfels, L.; Primet, M.; Tena, E.; Catal. Today 2003, 83, 45.

7. Ciuparu, D.; Lyubovsky, M. R.; Altman, E.; Pfefferle, L. D.; Datye, A.; Catal. Rev. 2002, 44, 593.

8. Deng, Y.; Nevell, T. G.; Catal. Today 1999, 47, 279.

9. Kucharczyk, B.; Tylus, W.; Kepinski, L.; Appl. Catal., B 2004, 149, 27.

10. Gélin, P.; Primet, M.; Appl. Catal., B 2002, 9, 1.

11. Simplício, L. M. T.; Brandão, S. T.; Sales, E. A.; Lietti, L.; BozonVerduraz, F.; Appl. Catal., B 2006, 63, 9.

12. Ribeiro, F. H.; Chow, M.; Dalla Beta, R. A.; J. Catal. 1994, 146, 537.

13. Escandón, L. S.; Ordóñez, S.; Vega, A.; Díez, F. V.; Chemosphere 2005, 58,9 .

14. Eguchi, K.; Arai, H.; Appl. Catal., A 2001, 222, 359.

15. Sekizawa, K.; Widjaja, H.; Maeda, S.; Ozawa, Y.; Eguchi, K.; Catal. Today 2000, 59, 69.

16. Sekizawa, K.; Widjaja, H.; Maeda, S.; Ozawa, Y.; Eguchi, K.; Appl. Catal., A 2000, 200, 211.

17. Yoshida, H.; Nakajima, T.; Yazawa, Y.; Hattori, T.; Appl. Catal., B 2007, 71,70 .

18. Simplício, L. M. T.; Brandão, S. T.; Domingos, D.; Bozon-Verduraz, F.; Sales, E. A.; Appl. Catal., A 2009, 360, 2.

19. Colussi, S.; Trovarelli, A.; Cristiani, C.; Lietti, L.; Groppi, G.; Catal. Today 2011, 180, 124.

20. Carstens, J. N.; Su, S. C.; Bell, A. T.; J. Catal. 1998, 176, 136.

21. Guerrero, S.; Araya, P.; Wolf, E. E.; Appl. Catal., A 2006, 298, 243.

22. Specchia, S.; Finocchio, E.; Busca, G.; Palmisano, P.; Specchia, V.; J. Catal. 2009, 263, 134.

23. Yang, S.; Valiente, A. M.; Gonzales, M. B.; Ramos, T. R.; Ruiz, A. G.; Appl. Catal., B 2000, 28, 223.

24. Hoflund, G. B.; Zhenhua, L.; Epling, W. S.; Göbel, T.; Schneider, P.; Hahn, H.; Catal. Lett. 2000, 70, 97.
25. Muller, C. A.; Maciejewski, M.; Koeppel, R. A.; Baiker, A.; J. Catal. 1997, 166, 36.

26. Su, S. C.; Carstens, J. N.; Bell, A. T.; J. Catal. 1998, 176, 125.

27. Fujimoto, K.; Ribeiro, F. H.; Borja, M. A.; Iglesia, E.; J. Catal. 1998, $179,431$.

28. Muller, C. A.; Maciejewski, M.; Koeppel, R. A.; Baiker, A.; Catal. Today 1999, 47, 245.

29. Hicks, R. F.; Qi, H.; Young, M. L.; Lee, R. G.; J. Catal. 1990, 122, 280.

30. Lyubovsky, M.; Pfefferle, L.; Appl. Catal., A 1998, 173, 107.

31. Grunwaldt, J. -D.; van Vegten, N.; Baiker, A.; Chem. Commun. 2007, 44,4635 .

32. van Vegten, N.; Maciejewski, M.; Krumeich, F.; Baiker, A.; Appl. Catal., B 2009, 93, 38.

33. Thevenin, P. O.; Pocoroba, E.; Pettersson, L. J.; Karhu, H.; Vayrynen, I. J.; Jaras, S. G.; J. Catal. 2002, 207, 139.

34. Church, J. S.; Cant, N. W.; Trimm, D. L.; Appl. Catal., A 1993, 101, 105.

35. Voogt, E. H.; Mens, A. J. M.; Gijzeman, O. L. J.; Geus, J. W.; Surf. Sci. 1996, 350, 21.

36. Voogt, E. H.; Mens, A. J. M.; Gijzeman, O. L. J.; Geus, J. W.; Catal. Today 1999, 47, 321

37. Brun, M.; Berthet, A.; Bertolini, J. C.; J. Electron Spectrosc. Relat. Phenom. 1999, 104, 55.

38. Suhonen, S.; Valden, M.; Pessa, M.; Savimaki, A.; Harkonen, M.; Hietikko, M.; Pursiainen, J.; Laitinen, R.; Appl. Catal., A 2001, 207, 113.

39. Sohn, J. M.; Kang, S. K.; Woo, S. I.; J. Mol. Catal. A: Chem. 2002, 186, 135.

40. Hoang, D. L.; Lieske, H.; Catal. Lett. 1994, 27, 33.

41. Farrauto, R. J.; Lampert, J. K.; Hobson, M. C.; Waterman, E. M.; Appl. Catal., B 1995, 6, 263. 